\title{
ON TORTULA CUNEIFOLIA (DICKS.) TURNER (POTTIACEAE, MUSCI) IN RUSSIA
}

\section{O TORTULA CUNEIFOLIA (DICKS.) TURNER (POTTIACEAE, MUSCI) В РОССИИ}

\author{
V. E. FEDOSOV 1 \\ В. Э. ФЕДОСОВ ${ }^{1}$
}

\begin{abstract}
Tortula cuneifolia (Dicks.) Turner, a submediterranean species, was found in Russia in Anabar Plateau in subarctic East Siberia. This is the northernmost of Eurasian localities of the species situated in more than $3000 \mathrm{~km}$ from the nearest locality in Tian-Shan Mountains in Middle Asia. The paper provides description and illustrations of plants that represent apparently a relic population occurring in xerophytic communities of North Siberia. A distinction of T. cuneifolia from similar species is discussed.
\end{abstract}

Резюме

Tortula cuneifolia (Dicks.) Turner, редкий вид с преимущественно средиземноморским евроазиатским распространением, впервые был найден в России на северо-западной периферии Анабарского плато (Таймырский р-н, Восточносибирская Субарктика). Это наиболее северное из известных местонахождений вида в Евразии, более чем на 3000 км удалённое от ближайшего местонахождения на Тянь-Шане. Сибирское местонахождение вида, вероятно, имеет реликтовую природу. Приводится описание и иллюстрации Сибирского образца и сравнение T. cuneifolia с близкими видами.

KEYWORDS: mosses, Pottiaceae, Tortula, new records, phytogeography, Russia, North Siberia, xerophytes

The Anabar Plateau is an area difficult of access in the subarctic of East Siberia. It has quite dry climate, with ca. $250 \mathrm{~mm}$ of annual precipitation, which in addition to limestone and dolomite bedrocks supports the xeric plant communities, similar to tundro-steppes of Yakutia and internal Alaska (Yurtsev, 1981; Murray, 1992). The recent exploration of the area revealed its high overall moss diversity and especially interesting composition of xeric species (Fedosov, 2007). Many of them exhibit extensive disjunction from the nearest localities in South Siberia or China (Anoectangium aestivum, Grimmia tergestina, Microbryum starckeanum, Syntrichia caninervis, Tortula muralis, etc.). One of them, Tortula cuneifolia, was recorded to be new for Russia, and its description and illustration are given here, along with the discussion of its distinction from superficially similar species and phytogeography.

Tortula cuneifolia (Dicks.) Turner, Muscol. Hibern. Spic., 51, 1804. - Bryum cuneifolium Dicks., Fasc. Pl. Crypt. Brit. 4: 29, 1801. — Figs. $1-3$.

Plants single or forming loose pale-green to yellowish-brown tufts. Stems erect, (0.3-) 0.5$0.8(-1.0) \mathrm{cm}$ high, with distinct central strand, moderately tomentose below, not or occasionally branched, densely foliate, upper leaves budlike crowded. Lower leaves minute, contorted then dry, ovate to lingulate and slightly keeled below. Up-

\footnotetext{
1 - Moscow State University, Biological Faculty, Moscow 119991 Russia - Россия 119991, Москва, Московский университет, Биологический факультет; e-mail: fedosov_v@mail.ru
} 


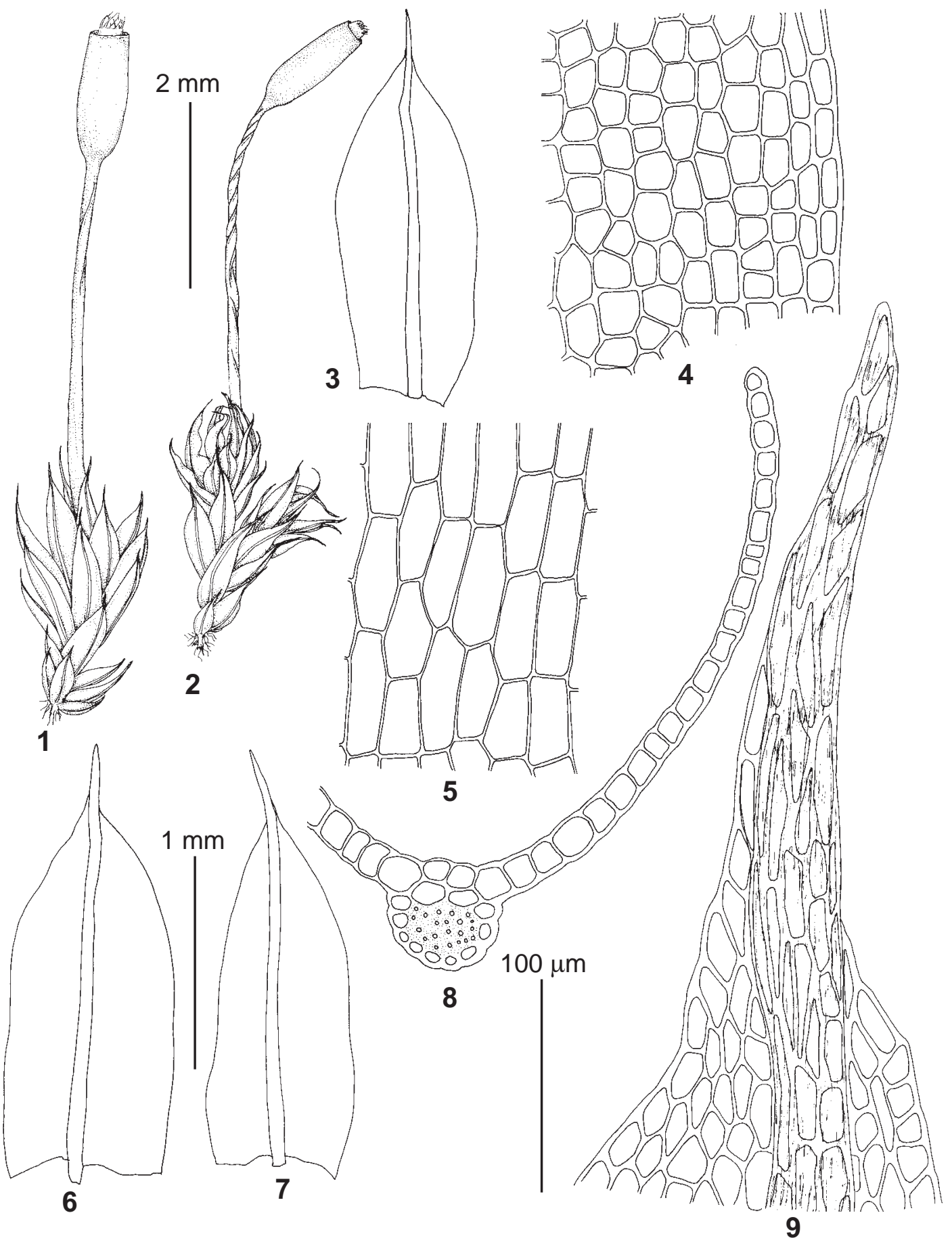

Fig. 1. Tortula cuneifolia (Dicks.) Turner (from: Russia, Taimyr, Fedosov \#06-324, MW): 1 - habit, wet; 2 habit, dry; 3, 6-7 - leaves; 4 - median laminal cells; 5 - basal laminal cells; 8 - leaf transverse section; 9 -upper laminal cells. Scale bars: $2 \mathrm{~mm}$ for 1-2; $1 \mathrm{~mm}$ for 3, 6-7; $100 \mu \mathrm{m}$ for 4-5, 8-9. 

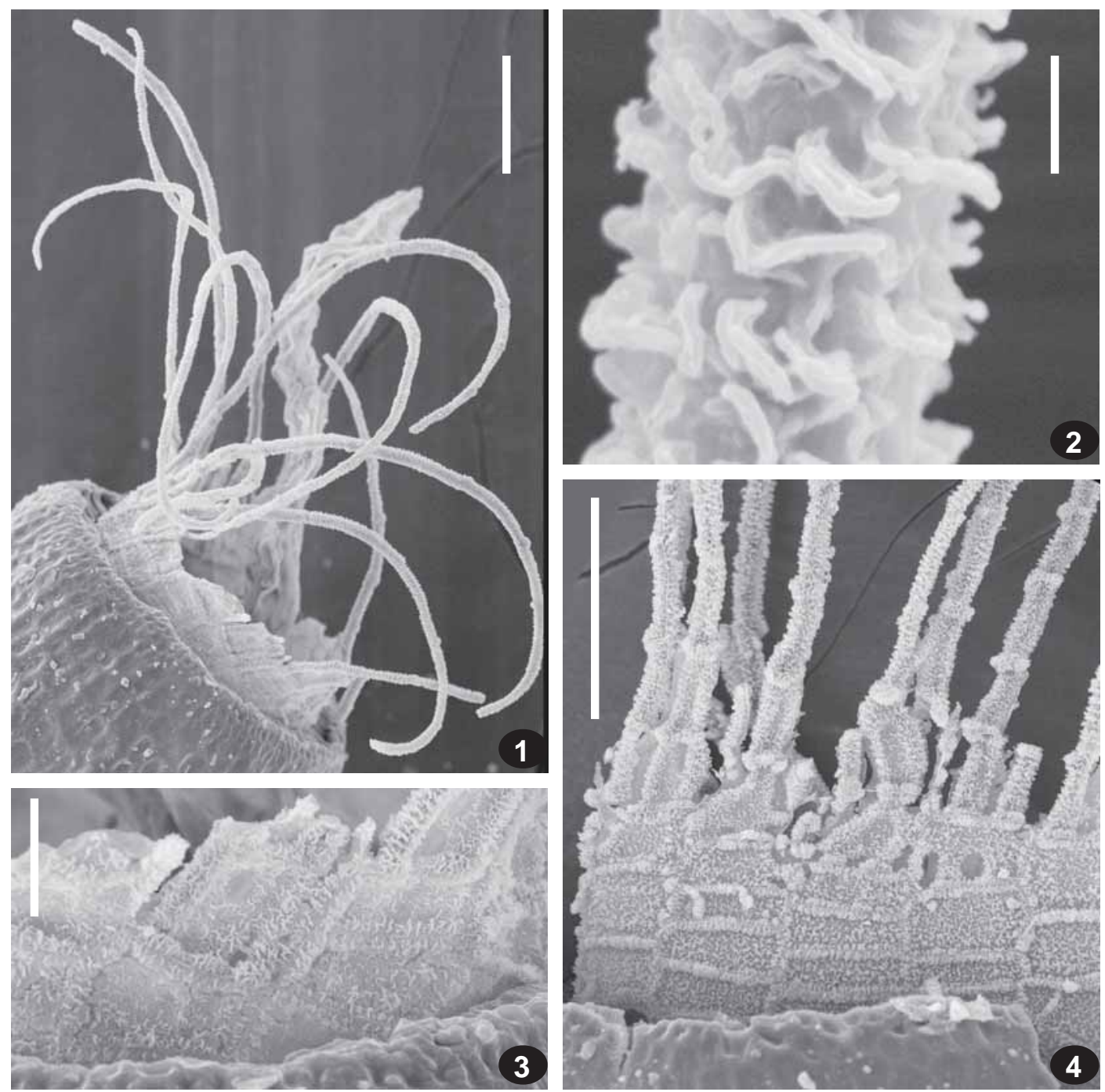

Fig. 2. Tortula cuneifolia (Dicks.) Turner (from: Russia, Taimyr, Fedosov \#06-324, MW): SEM pictures of peristome: 1 - overall view; 2 - segment in upper part; 3 - basal membrane; 4 - basal membrane with lower parts of segments. Scale bars: $100 \mu \mathrm{m}$ for $1 ; 3 \mu \mathrm{m}$ for $2 ; 30 \mu \mathrm{m}$ for $3 ; 100 \mu \mathrm{m}$ for 4 .

per leaves gradually enlarging, apically budlike, appressed, (1.2-)1.4-1.9(-2.0) ×0.4-0.6(-0.65) $\mathrm{mm}$, obovate to spatulate, broadly acute, strongly concave; margins entire and plane or slightly recurved from base to mid-leaf; costa at leaf base 30-50 $\mu \mathrm{m}$ broad, gradually narrowing upward, percurrent or, more often, excurrent in a smooth mucro to $0.3 \mathrm{~mm}$ long, green in upper leaves or yellowish in lower ones, in transverse section semicircular, smooth on both surfaces, mainly with 2 guide cells, well developed semicircular dorsal stereid band, without ventral stereid band, dorsal and ventral epidermis differentiated, upper laminal cells isodiametric, rounded-polygonal (12-)14$22(-25) \mu \mathrm{m}$, at leaf margins subquadrate or shortrectangular, thin-walled, smooth on both surfaces, at leaf base rectangular (35-)48-72(-85) $\times 16$ $23(-25) \mu \mathrm{m}$, very thin-walled, pale green or hyaline. Autoicous or paroicous. Setae 0.8-1.3 cm, brown. Capsule erect, short cylindric, often slightly curved, $1.5-2 \mathrm{~mm}$, brown; peristome pale below, pale-orange above; with low (about $100 \mu \mathrm{m}$ ) basal membrane; teeth cleft up to basal membrane, so represented by 32 filiform segments, about 600 
Fig. 3. World distribution of Tortula $\mathrm{cu}$ neifolia (solid circle) and Syntrichia caninervis (open square), showing different phytogeographic patterns.

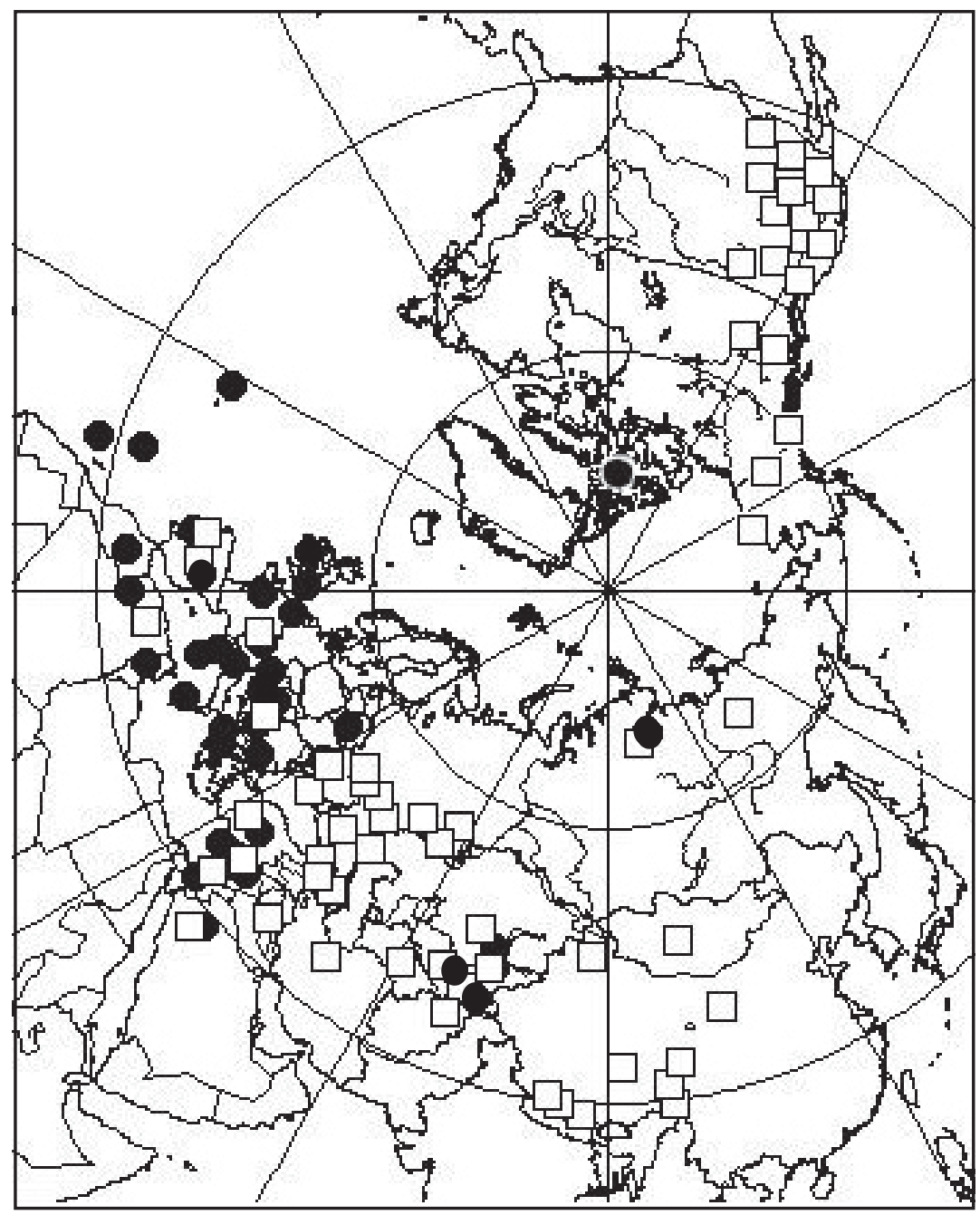

$\mu \mathrm{m}$ long, fragile, twisted counter-clockwise ca. 0.5 turn, papillose; annulus of 2(-3) cell rows, deciduous; lid brown, 1-1.7 mm high, narrowly conic, obtuse, lid cells in oblique rows. Spores 15-18 $\mu \mathrm{m}$, papillose.

In Europe capsules mature in spring (Smith, 1978), while in Anabar Plateau in July, i.e. when the mean day temperature starts to exceed $+10^{\circ} \mathrm{C}$.

Ecology. In Anabar Plateau T. cuneifolia was found on calcareous silt deposits on cliff ledges and near cliff bases. In Europe the species occurs on soil at the roadsides and ditch slopes, on stony walls, etc. (Smith, 1978; Savicz-Lyubitskaya \& Smirnova, 1970).

Specimens examined. ASIAN RUSSIA. Krasnoyarsk Territory, Taimyr District: Afanas'evskye Lakes, $71.5564^{\circ} \mathrm{N}, 106.188^{\circ} \mathrm{E}$, on dolomite cliff ledge, cov- ered by calcareous deposits layer on a rocky slope of stream canyon, Fedosov \#06-324 (MW); Valley of Kotuy River $10 \mathrm{~km}$ downstream from Kyndyn mouth, Kysyl-Haya, $70.9978^{\circ} \mathrm{N}, 102.699^{\circ} \mathrm{E}$, on calcareous silt, compact pure cushion among Ditrichum flexicaule, Stereodon vaucherii, Pterygoneurum ovatum, Fedosov \# 05-519 (MW) [here and further the nomeclature follows Ignatov, Afonina, Ignatova et al. (2006)].

Distribution. Tortula cuneifolia is a rare species with generally submediterranean distribution (Fig. 3). In some European countries it is included into regional red lists (Natcheva et al., 2006; Hodgetts, 2007; Hale, 2008). From a single type collection of T. cuneifolia var. blissii R.H.Zander (Nunavut, Cornwallis Island, vicinity of Resolute Bay, see below) the species is known for North America (Zander, 2007). 
The species has never been collected in Eurasian Subarctic yet. The closest known locality of species is in Tian-Shan Mountains in Middle Asia (Mamatkulov et al., 1998) in more than $3000 \mathrm{~km}$ from Anabar Plateau. Besides, the fact that the species was collected in two localities distant one from another to approximately $100 \mathrm{~km}$ excludes an explanation of its occurrence by occasional long-distance dispersal event. The occurrence in the area of a large number of other xerophytic mosses rather strongly isolated from their main ranges, supports the idea of a refugium for species which survived here the last glaciation. The area was never covered by the last glaciation completely. The similar situation is in Canadian Arctic where the second Arctic locality of the species is known: Cornwallis Island is also underlained by Ordovician and Devonian limestones and dolomites, has dry climate and likely was not totally glaciated (Broun et al., 2000).

Kürschner (2008) considered T. cuneifolia to be a species of circum-Mediterranean origin. However, its distribution in North America does not supports this view. "Typical” Circumthetian distribution, examplified by e.g. Syntrichia caninervis (cf. Murray, 1992) is different (Fig. 3), as this species is common in western North America (Zander, 2007), whereas T. cuneifolia is absent there.

Several alternative explanations of the origin of North American populations could be as follow. Tortula cuneifolia may penetrate to the North America from Europe: numerous localities with regular spore production at the distance of ca. 3000 $\mathrm{km}$ from Canadian locality are in United Kingdom and Ireland. The similar distance across the North Pole is also from the Anabar Plateau. And, the third possibility would be the migration from Siberia through Beringia. The latter scenario disagrees with the absense of $T$. cuneifolia in Yakutia, Chukotka and Alaska, but considering poor exploration of most of Arctic floras and difficulty to find this small moss makes this way not totally impossibe as well.

Tortula cuneifolia var. blissii R.H.Zander differs from typical variety by blackish gametophyte, short elliptic (not broadly obovate) leaves, that are apiculate (never grading to short awned), shorter seta $(0.4-0.5 \mathrm{~mm})$ and smaller spores $(12-15 \mu \mathrm{m})$.
Besides, it shows strong color $\mathrm{KOH}-$ reaction, not observed for the typical variety (Zander, 2007). However, this variety is known only from the type locality, and before the thorough study of its variation it is difficult to find out how much these differences are just a result of growth in unfavorable high Arctic environments.

Differentiation. Tortula cuneifolia is dictinct in smooth upper laminal cells, low basal membrane and peristome teeth twisted less than one turn. A comparison with some similar species can be as follow:

Tortula mucronifolia is distinct in high basal membrane and long (3-6 mm) urn.

Tortula deciduidentata (Sharp \& Z.Iwatsukii) R.H.Zander, known only from type locality in Aleutians, is distinct in much enlarged basal cells of leaf border, sharply truncate costa, and operculum pushed off by the elongating columella (Zander, 2007).

Tortula transcaspica Broth. differs in smaller plants (stem to $2 \mathrm{~mm}$, leaves $0.8 \mathrm{~mm}$ long), and larger spores 20-22 $\mu \mathrm{m}$ (Savicz-Lyubitskaya \& Smirnova, 1970).

Tortula ucrainica (Laz.) R.H.Zander has well differentiated leaf border and inclined capsule (Savicz-Lyubitskaya \& Smirnova, 1970).

\section{ACKNOWLEDGEMENTS}

I am grateful to Elena Ignatova for confirmation of specimens identification and preparing illustrations, and to Richard Zander for comments on the manuscript. The work was partly supported by RFBR, 07-04-00013 and by Scientific School Program HШ-4243-2008.4.

\section{LITERATURE CITED}

BROUN, C., D.R. HARDY, R.S. BRADLEY \& M.J. RETELLE 2000. Streamflow and Suspended Sediment Transfer to Lake Sophia, Cornwallis Island, Nunavut, Canada. Arctic, Antarctic, and Alpine Research 32, No. 4: 456-465.

[FEDOSOV, V.E.] ФЕДОСОВ В.Э. 2007. Новые находки мхов в Таймырском Автономном Округе. 2. - [New moss records from Taimyrskij Autonomous District. 2.] Arctoa 16: 192-197.

HALE, A. 2008. RDB Bryophytes in Wales. - http:// home.clara.net/adhale/bryos/gbrdb.htm.

HODGETTS, N. 2007. Threatened Bryophyte Database. http:/ /rbg-web2.rbge.org.uk/bbs/Bryodiversity/tbdp.htm.

IGNATOV, M.S., O.M. AFONINA, E.A. IGNATOVA et al. 2006. Check-list of mosses of East Europe and North Asia. - Arctoa 15: 1-130. 
KÜRSCHNER, H. 2008. Biogeography of South-West Asian Bryophytes - with special emphasis on the tropical element. - Turk. J. Bot. 32: 433-446

[MAMATKULOV, U. K., I. O. BAITULIN \& S. G. NESTEROVA] МАMАТКУЛОВ, У. К., И. О. БАЙТУЛИН, С. Г. НЕСТЕРОВА 1998. Мохообразные Средней Азии и Казахстана. - [Bryophytes of the Middle Asia and Kazakhstan] Aлматы [Almaty], 232.

MURRAY, B. 1992. Bryophyte flora of Alaskan steppes. Bryobrothera 1: 9-33.

NATCHEVA, R., A. GANEVA \& G. SPIRIDONOV 2006. Red List of the bryophytes in Bulgaria. - Phytologia Balcanica 12(1): 55-62.

[SAVICZ-LYUBITSKAYA, L.I. \& Z.N. SMIRNOVA] САВИЧ-ЛЮБИЦКАЯ Л.И., З.Н. СМИРНОВА 1970.
Определитель листостебельным мхов СССР. Верхоплодные мхи. - [Handbook of mosses of USSR. The acrocarpous mosses] Л., Наука [Leningrad, Nauka] $822 \mathrm{pp}$.

SMITH, A.J.E. 1978. The moss flora of Britain and Ireland. Cambridge, London, New-York, Melbourne, Cambridge university Press, 706 pp.

[YURTSEV, В.А.] ЮРЦЕВ Б.А. 1981. Реликтовые степные комплексы северо-восточной Азии. - [Relict steppe complexes of North-East Asia] Новосибирск, Наука [Nauka, Novosibirsk].

ZANDER, R.H. 2007. Pottiaceae. - In: Zander R.H. (ed.) Flora of North America North of Mexico. Oxford University Press: New-York 27: 476-642. 